\title{
$\beta$-シクロデキストリン誘導体による光照射時のクロル プロマジン接触性皮膚炎の軽減とその機構解明
}

\author{
石田 和久, 星野 輝彦, 入江 徹美, 上釜 兼人 \\ 熊本大学薬学部・製剂学研究室 $\overline{\mathrm{T}} 862$ 熊本市大江本町5-1
}

Key words : chlorpromazine, cyclodextrin, phototoxic contact dermatitis, inclusion complex, guinea pig

\section{Alleviation of Chlorpromazine-Photosensitized Contact Dermatitis by $\beta$-Cyclodextrin Derivatives and Their Possible Mechanisms \\ Kazuhisa Ishida, Teruhiko Hoshino, Tetsumi IrIE and Kaneto Uekama Faculty of Pharmaceutical Sciences, Kumamoto University, 5-1 Oe-honmachi, Kumamoto 862, Japan}

\begin{abstract}
Summary
$\beta$-Cyclodextrin $(\beta-\mathrm{CyD})$, heptakis $(2,6-\mathrm{di}-\mathrm{O}-$-methyl $)-\beta-\mathrm{CyD}(\mathrm{DM}-\beta-\mathrm{CyD})$ and 2 -hydroxypropyl- $\beta$ - $\mathrm{CyD}(\mathrm{HP}-\beta-\mathrm{CyD}$, substitution degree 4 .3) were found to alleviate the phototoxic contact dermatitis induced by chlorpromazine hydrochloride (CPZ), a typical antipsychotic agent, in dorsal skin of guinea pigs. The inhibitory effect of $\mathrm{CyDs}$ was in the following order $\mathrm{DM}-\beta-\mathrm{CyD}>\beta-\mathrm{CyD}>\mathrm{HP}-\beta-\mathrm{CyD}$, depending on the magnitude of the stability constants of $\mathrm{CPZ}-\mathrm{CyD}$ complexes. The percutaneous absorption of $\mathrm{CPZ}$ was inhibited particularly by $\mathrm{DM}-\beta-\mathrm{CyD}$. The photoreaction pathway of $\mathrm{CPZ}$ in the skin was changed by $\mathrm{CyDs}$, i.e. less toxic promazine was predominantly produced in the presence of $\mathrm{CyDs}(\mathrm{DM}-\beta-\mathrm{CyD} \geqq \beta-\mathrm{CyD}>\mathrm{HP}-\beta-\mathrm{CyD})$.

The results indicate that the alleviative effects of $\mathrm{CyDs}$ may be attributable to the reduction of percutaneous absorption of $\mathrm{CPZ}$ and the alternation in phototoxic reaction pathway of $\mathrm{CPZ}$ through inclusion complexation.
\end{abstract}




\section{緒 言}

代表的なフェノチアシシン系薬物である塩酸クロ ルプロマジン $(\mathrm{CPZ})$ は, 精神病や神経症の病状 改善に優れた効果を発揮することから, 現在精神 科領域で広く使用されている。しかしながら， $\mathrm{CPZ}$ は服薬患者だけでなく薬物に直接接触する 機会のある製造業者, 医療従事者, 研究者などに も比較的高い頻度で光感作性皮膚障害を惹き起こ すことが知られており，臨床使用上および労働衛 生上その安全性が問題となる プの皮膚反応には，現在有効な予防策や本質的な 治療法がなく，製剤加工上の工夫による毒性の軽 減に期待が寄せられている。

環状オリゴ糖であるシクロデキストリン $(\mathrm{CyD})$ は多方面で応用され, 中でる薬剤学, 製剂学領域 に扣いては, 医薬品の安定化, 溶解性の調節, バ イオアベイラビリティーの向上, 局所刺激性の軽 減などに広く利用されている2,3,4). 最近では, 天 然 $\mathrm{CyD}$ の物性を改良し機能性を高めるため, 種 々の誘導体や共重合体の研究開発が活発に行われ ている ${ }^{5)}$. 例光ば, $\beta-\mathrm{CyD}$ の 2,6 位の水酸基を メチル化した heptakis (2,6-di-O-methyl)- $\beta$ cyclodextrin (DM- $\beta-\mathrm{CyD})$ 杼よび主に 6 位の水 酸基をヒドロキシプロピル化した 2 -hydroxypropyl- $\beta-\mathrm{CyD}(\mathrm{HP}-\beta-\mathrm{CyD})$ は, $\beta-\mathrm{CyD}$ に比べて 優れた物性や包接能を有することから製剂への有 效利用が期待されている ${ }^{6,7,8)}$. そこで, 本研究で は 3 種の $\mathrm{CyD}(\beta-\mathrm{CyD}, \mathrm{DM}-\beta-\mathrm{CyD}$ および $\mathrm{HP}-$ $\beta-\mathrm{CyD})$ との複合体形成による $\mathrm{CPZ}$ の接触性光 毒作用の軽減を目的として検討を行い,さらにそ の軽減機構について考察を加えた.

\section{実験材料および実験方法}

\section{1. 試 料}

$\mathrm{CPZ}$ は吉富製薬(秼)より, 塩酸プロマジン $(\mathrm{PZ})$ は塩野義製薬(侏より恵与されたものを使用した. $\beta-\mathrm{CyD}$ は日本食品化工侏製のものを, DM- $\beta$ $\mathrm{CyD}$ は東進ケミカル陎製のものを，とれぞれ水 から再結晶して使用した。 HP- $\beta-\mathrm{CyD}$ [置換度 (D.S.) 4.3]は東進ケミカル侏製のものを使用し た. 溶媒としての水はイオン交換精製水を 2 回蒸 留して用いた，他の試薬および溶媒はすべて市販
特級品を用いた。

\section{2. 安定度定数}

$\mathrm{CPZ}$ と $\mathrm{CyD}$ との複合体形成の安定度定数は, $\mathrm{CyD}$ 添加による薬物の UV 吸収スペクトル変化

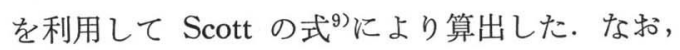
測定には島津製作所侏製 UV-160 形を用い, 測定 波長 $250 \mathrm{~nm}$ で定量した.

\section{3. クロルプロマジンの皮膚への適用}

実験にはモルモット（雌性ハートレー系, 350$400 \mathrm{~g}$ ）の背部皮膚を電気カミソリで除毛後， 24 時間経過した皮虐を使用した.モルモットを固定 後, 背部皮膚 4 力所に濾紙 $\left(1 \times 1 \mathrm{~cm}^{2}\right)$ を 2 枚重 ねにして置き, $\mathrm{CPZ}\left(5 \times 10^{-2} \mathrm{M}\right)$ 扎よび $\mathrm{CyD}(5 \times$ $\left.10^{-2} \mathrm{M}\right)$ 混液を $50 \mu l$ ずつ滴下し，その上をアル ミ箔 $\left(1.2 \times 1.2 \mathrm{~cm}^{2}\right)$ で覆い, さらにニチバン® (日本薬局方絆創高) で密封固定した，一定時間 後，水を含んだ紙片を用いて貼布した皮膚面を軽 く拭さ10)，付着している CPZ を除去した。これ らの操作は, $\mathrm{CPZ}$ の光分解を避けるためすべて暗 室で行った.

\section{4. 光照射条件}

光源として UV-A 領域 ( >315 nm) に中心波 長をもつ東芝秼製医療用紫外線ランプ (FL 20 SBLB 型) を用い, ガラスフィルターを通して短 波長側を遮光した. 照度は $2.7 \mathrm{~mW} / \mathrm{cm}^{2}(365 \mathrm{~nm})$ で63分間光照射した.

\section{5. 皮膚反応の評価}

光照射により惹起される皮膚反応について，特 に色素沈着の程度を次のような基準で評価した。

変化なし…………………….... 0

ごく軽度の色素沈着……………... 1

明らかな色素沈着………………2 2

中～強度の色素沈着………………3

また, 投与部位の組織切片は, 常法 ${ }^{11)}$ に従いへ マトキシリンーエオジン重染色後, 顕微鏡下で病 理組織学的に検討した.

\section{6. 瀘紙中薬物濃度}

CPZ を貼布後, 貼布した濾紙, 皮膚表面, ア ルミ䇴に付着した CPZ を拭き取った紙片に0.1N 水酸化ナトリウム水溶液 $1 \mathrm{~m} l$, 水 $2 \mathrm{~m} l$ 扎よびェ ーテル $5 \mathrm{ml}$ を加光, 30分間振盪した. 遠心分離 後 $(800 \times \mathrm{g}, 5 \mathrm{~min})$, エーテル層 $4 \mathrm{~m} l$ を採取し, 内部標準物質 (フタル酸ジノニル) を添加後, ガ 
スクロマトグラフィー (GC) により $\mathrm{CPZ}$ を定量 した.

GC 測定条件 : 検出器は島津製作所(秼製 FID-6 型水素炎イオン化検出器を用い, ガラスカラム (3 i.d. $\times 600 \mathrm{~mm}$ ) の充填剤には $1 \% \mathrm{SE}-52$ on 60〜80 mesh Gas-chrom Q (ガスクロ工業(制製) を使用した。注入温度 $280^{\circ} \mathrm{C}$ ，カラム 温 度 265 $270^{\circ} \mathrm{C}$, キャリヤガス (窒素) 压力 $1 \mathrm{~kg} / \mathrm{cm}^{2}$ で操 作した.

\section{7. 皮膚中 $\mathrm{CPZ}$ または $\mathrm{CyDs}$ 濃度の測定}

モルモット背部皮膚に試料を貼布後, よく拭き 取ってから殺し，貼布部位の皮膚を $1 \times 1 \mathrm{~cm}^{2}$ の 区画で切り取り，細かく刻んだ。なお，角質は Washitake らの方法 ${ }^{12)}$ に準じてスコッチテープ® (3 M M-18) で20回剝離することにより採取 し た. $\mathrm{CPZ}$ の場合, 被験皮膚またはテープを $2 \mathrm{ml}$ の水中に入れ, $50^{\circ} \mathrm{C}$ で 2 時間振燙した. $\mathrm{CPZ}$ およ びPZ の抽出操作並びに定量法は前記と同様に行 った。 $\beta$-CyD の場合, 被験皮膚またはテープを $3 \mathrm{~m} l$ の水中に入れ, $50^{\circ} \mathrm{C} て ゙ 2$ 時間振盪した。遠 心分離後 $(800 \times \mathrm{g}, 5 \mathrm{~min})$, 上清 $1 \mathrm{~m} l$ 採取し内 部標準物質 $(\gamma-\mathrm{CyD})$ を添加後, 蒸発乾固した. 残渣にピリジン $0.2 \mathrm{~m} l$ 打よびイソシアン酸フェ ニル $0.4 \mathrm{~m} l$ を加光, 暗所において $50^{\circ} \mathrm{C} て ゙ ~ 1$ 時間 振盪することにより UV ラベル化した ${ }^{13)}$. 反応 液の溶媒を留去後, 残渣をメタノールに溶かし, 液体クロマトグラフィー（HPLC）により定量し た. $\mathrm{DM}-\beta-\mathrm{CyD}$ の場合, 被験皮䖉またはテープ を $3 \mathrm{~m} l$ の水中に入れ, 内部標準物 質 (DM- $\gamma-$ CyD）を加光， $50^{\circ} \mathrm{C}$ で 2 時間振壍した．遠心分離 後 $(800 \times \mathrm{g}, 5 \mathrm{~min})$, 水系メンブランフィルター

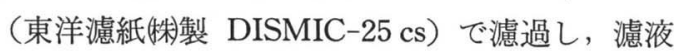
を蒸発乾固後, 下記の HPLC の移動相に溶かし 定量した.

$\boldsymbol{\beta}$-CyD の測定条件：ポンプは日立侏製 655 型 液体クロマトグラフ, 検出器はアトー侏製 SF1204 型波長可変 UV モニターを用い，測定波長 $230 \mathrm{~mm}$, 流速 $1.0 \mathrm{ml} / \mathrm{min}$ で操作した. カラム はエルマ光学(制製 ERC-ODS-1161 (6 i.d. ×100 $\mathrm{mm})$ を用い, 移動相にはアセトニトリルー水 $(98$ : $2 \mathrm{v} / \mathrm{v})$ 混液を使用した.

DM- $\boldsymbol{\beta}$-CyD の測定条件：ポンプは日立侏製 L-6000型液体クロマトグラフ, 検出器は昭和電工
侏製 shodex RI SE-51 示差屈折計を用い, 流速 $1.0 \mathrm{ml} / \mathrm{min}$ で操作した. カラムは山村化学秼製 R-ODS-5 (4.6 i.d. $\times 250 \mathrm{~mm}$ )を，移動相にはア セトニトリルー水 $(55: 45 \mathrm{v} / \mathrm{v})$ 混液を使用し た.

\section{In vitro 膜透過実験}

隔膜として雌性へアレスマウス (HRS/J 系, $8 \sim 10$ 週㱓) の背部皮膚（厚さ $0.07 \mathrm{~cm})^{14}$ ) 用 い, 垂直型拡散セル（透過面積 $0.85 \mathrm{~cm}^{2}$ ) にクリ ップで固定した. ドナーセルには $\mathrm{CPZ}$ および $\mathrm{CyD}$ 濃度がそれぞれ $5 \times 10^{-2} \mathrm{M}, 3.75 \times 10^{-2} \mathrm{M}$ の 生理食塩水溶液 $(0.5 \mathrm{~m} l)$ を入れ, レセプターセ ルには生理食塩水 $(9 \mathrm{~m} l)$ を入れ, シンク条件が 保たれるようにレセプターセル側をマグネットス ターラーで攪拌した。な招, 実験は $25^{\circ} \mathrm{C}$, 遮光条 件下で行った. 経時的にレセプターセルから試料 溶液 $1 \mathrm{~m} l$ を採取し, 内部標準物質（プロトリプ チリン)を添加し蒸発乾固後, 下記の HPLC の 移動相に溶かし定量した。な执, 被検液採取後は 同温同容量の生理塩水を加えてレセプターセル内 の溶液量を一定に保った。

HPLC 測定条件：ポンプは日立诛製 $635 \mathrm{~A}$ 型 液体クロマトグラフ, 検出器は日立(侏製 638-41 A 型波長可変 UV モニターを用い, 測定波長 $250 \mathrm{~nm}$, 流速 $2.0 \mathrm{ml} / \mathrm{min}$ で操作した. カラムはガスクロ 工業侏製 Partisil-10 ODS (4.6 i.d. $\times 250 \mathrm{~mm}$ ) を, 移動相にはアセトニトリルー $50 \mathrm{mM}$ 酢酸ア ソモニウム緩衝液（pH 4.3）（7：3 v/v）混液を 使用した.

\section{9. 光分解産物の定量}

$\mathrm{CPZ}$ をモルモッ背部皮膚に貼布後光照射し, 生成する $\mathrm{PZ}{ }^{15)}$, 前記の $\mathrm{CPZ}$ の定量法と同様 に GC により定量した.

\section{ESR スペクトルの測定}

モルモット皮膚に CPZ を貼布後, 貼布部位の 皮膚を摘出し，外科用メスで脂肪を取り除いた. 減圧乾燥器 $\left(25^{\circ} \mathrm{C}, 0 \mathrm{mmHg}\right)$ て 24 時間乾燥し, 水分を留去した皮膚を $50.0 \mathrm{mg}$ の大きさに切り 取り, 石英セルに入れ, 角質層側から 5 分間光照 射した. 光源にはNUM 用クセノン照射装置 (二 ニオン光学(秼製) を使用した. ESR スペクトル は電子スピン共鳴装置 (日本電子(秼) 製, JES-FE 型）を使用し，室温で測定した。 
ESR 測定条件 : 磁場 $3350 \pm 50 \mathrm{G}$, マイクロ波 周波数 $9.38 \mathrm{GHz}$, 磁場掃引時間 $6 \mathrm{~min}$, 磁場変調 周波数 $100 \mathrm{KHz}$, 磁場変調幅 $0.8 \mathrm{G}$, 増幅比 7.9 $\times 1000$, 応答時間 $0.3 \mathrm{sec}$.

\section{結果と考察}

\section{1. $\mathrm{CPZ}$ の光接触性皮膚反応に及ぼす各種 CyD の影響}

$\mathrm{CPZ}$ の接触性光毒作用の臨床症状は, 接触 乙 た部位に打将灰色の色素沈着, 発赤, 浮腫, か ゆみなどの炎症反応を特徵としている ${ }^{16,17)}$. Fig. 1 および2は，モルモット背部皮膚に $\mathrm{CPZ，また}$ はその $\mathrm{CyD}$ 複合体を含む濾紙を貼布後, 光照射 により惹起される皮膚区応を, 肉眼的および病理

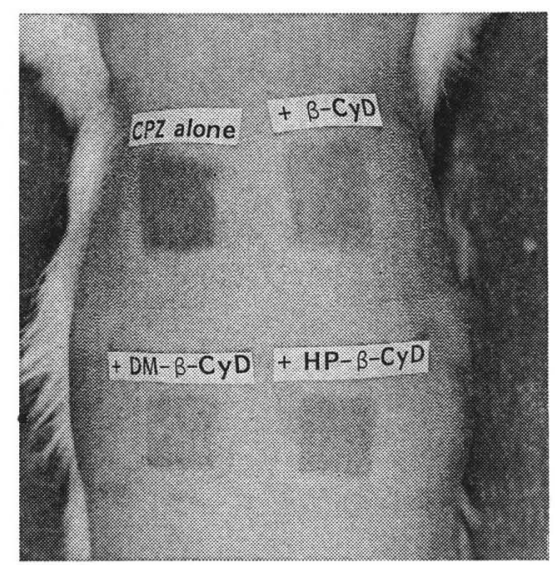

Fig. 1. Macrographs of the Skin Showing on Immediate Reaction Induced by $\mathrm{CPZ}$ $\left(5 \times 10^{-2} \mathrm{M}\right)$ in the Absence and Presence of $\mathrm{CyDs}\left(5 \times 10^{-2} \mathrm{M}\right)$ after Photoirradiation of Dorsal Skin of Guinea Pigs

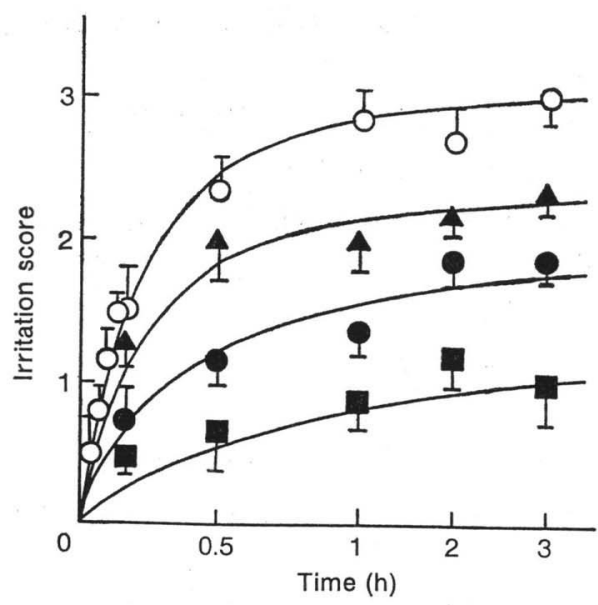

Fig. 3. Effects of CyDs $\left(5 \times 10^{-2} \mathrm{M}\right)$ on Phototoxic Irritating Reactions Induced by $\mathrm{CPZ}\left(5 \times 10^{-2} \mathrm{M}\right)$ after Application to Dorsal Skin of Guinea Pigs
$\mathrm{O}: \mathrm{CPZ}$,
$\mathrm{CPZ}+\beta-\mathrm{CyD}$
$\mathrm{CyD}, \boldsymbol{\Delta}: \mathrm{CPZ}+\mathrm{HP}-\beta-\mathrm{CyD}$.

Each point represents the mean \pm S.E. of 5 guinea pigs.

\section{組織学的に観察した結果を示す.}

Fig. 3 は貼布時間を変化した時の皮膚反応を肉 眼的に評価した結果を示す.な打, $\mathrm{CPZ}$ の光接触 性皮膚反応は, 光照射直後が最も強いことから, すべて光照射直後に評価を行った．Fig. 1 に示す よらに, $\mathrm{CPZ}$ 単独では貼布部位の皮膚に主として 灰色の色素沈着が観察された。これらの皮膚反応 を顕微鏡下で観察すると，表皮において過角化が 著明であり，部分的に顆粒層の肥大化も認められ た、また，真皮では特にその上層において浮腫，

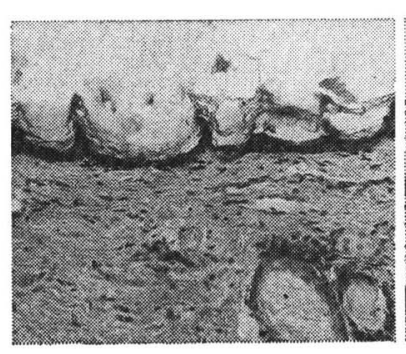

Control

(x 200)

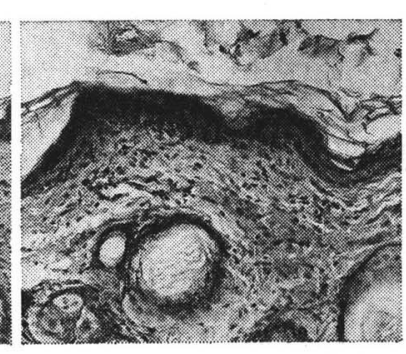

$\mathrm{CPZ}$ alone $(\mathrm{A})$

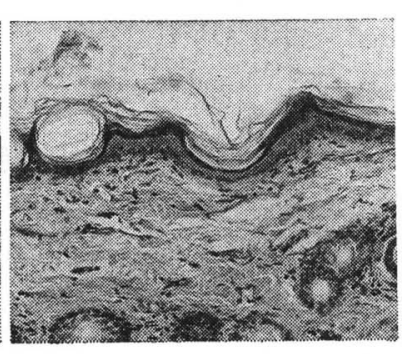

$C P Z+D M-\beta-C y D$ (x 200)

Fig. 2. Micrographs of the Skin Showing on Immediate Reaction Induced by $\mathrm{CPZ}$ $\left(5 \times 10^{-2} \mathrm{M}\right)$ in the Absence and Presence of CyDs $\left(5 \times 10^{-2} \mathrm{M}\right)$ after Photoirradiation of Dorsal Skin of Guinea Pigs 
(A)

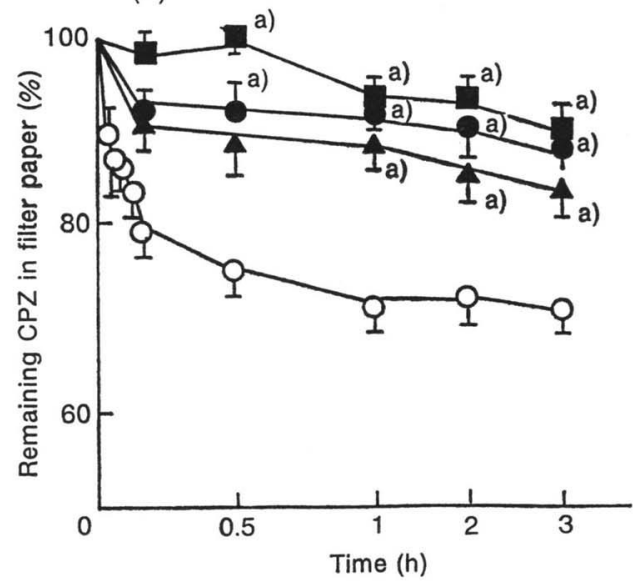

(B)

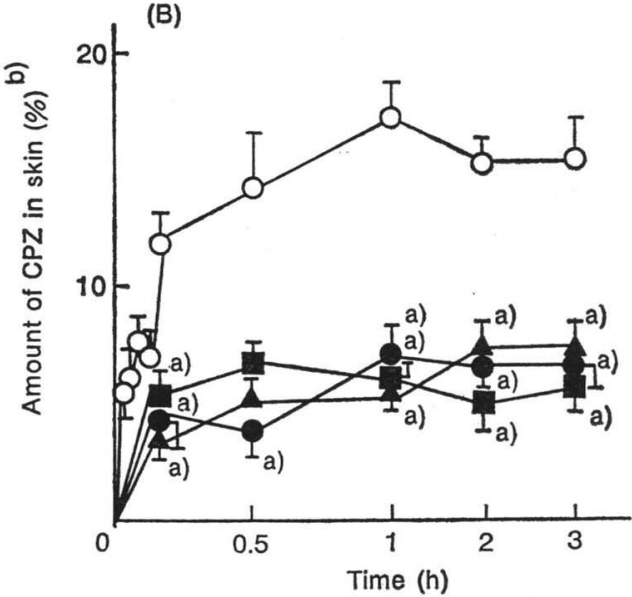

Fig. 4. Elimination (A) and Absorption (B) Profiles of CPZ from Filter Paper Containing CPZ or Its CyD Complexes (equivalent to $888 \mu \mathrm{g} \mathrm{CPZ}$ ) after Application to Dorsal Skin of Guinea Pigs

$\mathrm{O}: \mathrm{CPZ}, \mathrm{CPZ}+\beta-\mathrm{CyD}, \mathrm{CPZ}+\mathrm{DM}-\beta-\mathrm{CyD}$,

Each point represents the mean \pm S.E. of 5 guinea pigs.

a) $p<0.05$ versus $(\mathrm{O})$.

b) The percent in ordinate indicates the ratio to total amount of CPZ.

Table I. Effects of $\mathrm{CyDs}$ on the Distribution of $\mathrm{CPZ}$ in Dorsal Skin of Guinea Pigs

\begin{tabular}{lcccc}
\hline \hline System & $\begin{array}{c}\text { In } \\
\text { stratum corneum } \\
\left(\mu \mathrm{g} / \mathrm{cm}^{2}, \mathrm{~A}\right)\end{array}$ & $\begin{array}{c}\text { Under } \\
\text { stratum corneum } \\
\left(\mu \mathrm{g} / \mathrm{cm}^{2}, \mathrm{~B}\right)\end{array}$ & $\begin{array}{c}\text { Total } \\
\text { amount } \\
\left(\mu \mathrm{g} / \mathrm{cm}^{2}, \mathrm{~A}+\mathrm{B}\right)\end{array}$ & $\begin{array}{c}\mathrm{A} / \mathrm{A}+\mathrm{B} \\
(\%)\end{array}$ \\
\hline CPZ alone & $101.8 \pm 5.3$ & $95.1 \pm 12.2$ & $196.9 \pm 16.8$ & $52.0 \pm 2.4$ \\
with $\beta-\mathrm{CyD}$ & $39.4 \pm 3.2$ & $33.8 \pm 3.7$ & $73.2 \pm 6.8$ & $53.7 \pm 0.9$ \\
with DM- $\beta-\mathrm{CyD}$ & $56.5 \pm 10.3^{*}$ & $22.2 \pm 1.7$ & $78.8 \pm 10.2$ & $70.4 \pm 4.2^{* *}$ \\
with HP- $\beta$-CyD & $30.0 \pm 6.5$ & $35.3 \pm 4.2$ & $65.3 \pm 8.9$ & $44.8 \pm 5.5$ \\
\hline
\end{tabular}

a) Amount stripped with $\operatorname{Scotch}{ }^{\circledR}$ tape $(3 \mathrm{M} \mathrm{M}-18)$ twenty times successively.

b) Amount in stripped skin.

Each value represents the mean \pm S.E. of 5 guinea pigs.

$* p<0.05$ versus $\mathrm{B}$.

** $p<0.05$ versus $\mathrm{CPZ}$ alone.

血管拡張括よびリソパ球などの炎症性細胞浸潤が 認められた（Fig. $2 \mathrm{~A}$ )。な拉，本実験条件下では $\mathrm{CPZ}$ 自身による接触性皮膚反応はほとんど 認め られないこと，また $\mathrm{CPZ}$ の光接触性皮膚反応は, 貼付時間（Fig. 3) および光照射時間の経過とと もに増大寸ることなどから, CPZ の接触性光毒作 用には, 薬物の経皮吸収扣よび皮膚中光分解反応 が関与することが示唆された.一方, 各種 $\mathrm{CyD}$ 存在下に打ける $\mathrm{CPZ}$ の接触性光毒作用は, 肉眼 的ならびに病理組織学的にも顕著に抑制され，そ の抑制効果は複合体の安定度定数の大きさに応じ $\tau, \mathrm{DM}-\beta-\mathrm{CyD}\left(8800 \mathrm{M}^{-1}\right)>\beta-\mathrm{CyD}\left(8300 \mathrm{M}^{-1}\right)$ $>\mathrm{HP}-\beta-\mathrm{CyD}\left(4400 \mathrm{M}^{-1}\right)$ の順であった.

\section{2. $\mathrm{CPZ}$ の経皮吸収に及ぼす各種 $\mathrm{CyD}$ の影響}

$\mathrm{CPZ}$ の光接触性皮膚反応の強度は, 皮膚中に 存在する薬物の量やその分布部位などにより変化 するものと考光られる。たと光ば，比較的高濃度 の $\mathrm{CPZ}$ が角質層以下の表皮扣よび真皮に分布し 光照射されると，重篤な皮膚反応を惹起すること が知られている18).

Fig. 4 は， CPZ または CyD 混液を含む滤紙 をモルモット背部皮膚に貼布後, $\mathrm{CPZ}$ の濾紙中残 
Table II. Distribution of CyDs in Dorsal Skin of Guinea Pigs

\begin{tabular}{|c|c|c|c|}
\hline System & $\begin{array}{c}\text { Total } \\
\text { amount } \\
\left(\mu \mathrm{g} / \mathrm{cm}^{2}\right)\end{array}$ & $\begin{array}{ll}\text { In } \\
\text { stratum } \\
\text { corneum } \\
(\%)\end{array}$ & $\begin{array}{c}\text { Under } \\
\left.\text { stratum corneum }{ }^{\mathrm{b}}\right) \\
(\%)\end{array}$ \\
\hline $\mathrm{CPZ}+\beta-\mathrm{CyD}$ & $35.2 \pm 0.8$ & $64.5 \pm 2.5$ & $35.5 \pm 3.0$ \\
\hline $\mathrm{CPZ}+\mathrm{DM}-\boldsymbol{\beta}-\mathrm{CyD}$ & $24.3 \pm 3.3^{*}$ & $48.9 \pm 5.4^{*}$ & $51.1 \pm 5.4^{*}$ \\
\hline
\end{tabular}

a) Amount stripped with Scotch tape $\bigotimes^{\circledR}(3 \mathrm{M} M-18)$ twenty times successively.

b) Amount in stripped skin.

Each value represents the mean \pm S.E. of 5 guinea pigs.

$* p<0.05$ versus $\beta-\mathrm{CyD}$.

存率叔よび皮膚中量の経時変化を示す．

濾紙からの $\mathrm{CPZ}$ の消失量蛙よび皮㲊中存在量 は, $\mathrm{CyD}$ 存在下で著しく抑制されることから, $\mathrm{CPZ}$ の光接触性皮膚反応に対する $\mathrm{CyD}$ の抑制効果の 一因として, 複合体形成に上る $\mathrm{CPZ}$ の経皮吸収 性の低下が考光られる. しかし，その効果は 3 種 の $\mathrm{CyD}$ 間でほとんぞ差が認められないことか ら， CPZ の経皮吸収性の低下に加光て他の因子む 複雑に関与していることが推察される。

Table I は, CPZ 抢よび $\mathrm{CyD}$ 混液を含も濾 紙を 3 時間貼布後, 皮膚中に存在する $\mathrm{CPZ}$ の角 質層㧍よびそれ以下の組織への分布を示す. CPZ 単独の場合, 角質層扩よびそれ以下の組織中に汪 淮同じ割合で存在するのに対して, DM- $\beta-\mathrm{CyD}$ 存在下では, 角質層以下の組織よりも角質層に高 濃度に分布し, CPZ の皮虐深部への浸透抑制が認 められた。

Table II は, $\mathrm{CPZ}$ の $\mathrm{CyD}$ 複合体溶液を含む 滤紙を 3 時間貼布後, 皮膚中に存在する $\mathrm{CyD}$ 量 拈よびその分布を示す. $\beta-C y D$ 拉よび DM- $\beta-$ $\mathrm{CyD}$ 自身の皮膚中濃度は $\mathrm{CPZ}$ に比べて少な く，委たその分布は $\beta-\mathrm{CyD}$ が角質層に高濃度に 存在するのに対して, DM- $\beta-\mathrm{CyD}$ では角質層拉 よびそれ以下の組織中にも同じ割合で存在した. なお，HP- $\beta$-CyD 系では HPLC による微量定 量法が確立していないため, 皮膚中 $\mathrm{HP}-\beta-\mathrm{CyD}$ 濃度の測定は困難であった。

以上の知見より, 3 種の $\mathrm{CyD}$ の中で特に $\mathrm{DM}-$ $\beta-\mathrm{CyD}$ は, 複合体形成に上り $\mathrm{CPZ}$ の皮虐への 移行並びに皮膚深部への浸透を抑制し, その結 果, 光接触性皮膚反応を軽減するものと考兄られ る.

\section{3. $\mathrm{CPZ} の$ in vitro 膜透過性に及はすす $\mathrm{CyD}$ の影響}

次に, 各種 $\mathrm{CyD}$ との複合体形成による $\mathrm{CPZ}$ の皮膚透過抑制機構を明らかとするため, へアレ スマウスの摘出背部皮膚を用いて検討を行った。

Fig. 5 は, 垂直型拡散セルのドナーセルに一定 濃度の $\mathrm{CPZ}$, またはその $\mathrm{CyD}$ 混液を用いた場合 の CPZ の膜透過挙動を示す. CPZ の累積透過量 は $\mathrm{CyD}$ 添加に上り低下し, その効果は安定度定 数の大きさによく対応して,DM- $\beta-\mathrm{CyD}>\beta-\mathrm{CyD}$ $>\mathrm{HP}-\beta-\mathrm{CyD}$ の順であった.

Table III は, Fig. 5 の結果を Okamoto ら ${ }^{19)}$ の方法にしたがって解析して得られた CPZ の膜 透過パラメータを示す. Table III に示すように,

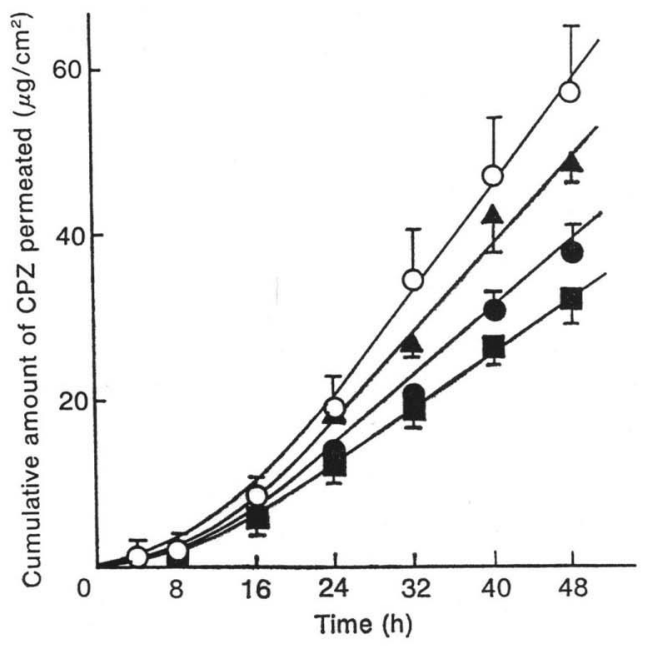

Fig. 5. Effects of CyDs $\left(3.75 \times 10^{-2} \mathrm{M}\right)$ on $\mathrm{CPZ}$ $\left(5.0 \times 10^{-2} \mathrm{M}\right)$ Permeation through Hairless Mice Skin

$\mathrm{O}: \mathrm{CPZ}, \quad \mathrm{:CPZ}+\beta-\mathrm{CyD}$,

$\mathrm{CyD}, \quad \boldsymbol{\Delta}: \mathrm{CPZ}+\mathrm{HP}-\beta-\mathrm{CyD}$.

Each point represents the mean \pm S.E. of 3 mice. 
Table III. Parameters for Percutaneous Penetration of $\mathrm{CPZ}^{\mathrm{a}}$ ) with and without $\mathrm{CyDs}^{\mathrm{b})}$

\begin{tabular}{lcccc}
\hline System & $\begin{array}{c}\left.\mathrm{D}^{\mathrm{c}}\right) \\
\left(\times 10^{5} \mathrm{~cm}^{2} / \mathrm{h}\right)\end{array}$ & $\begin{array}{c}\left.\mathrm{K}^{\mathrm{d}}\right) \\
\left(\times 10^{2}\right)\end{array}$ & $\begin{array}{c}\mathrm{Pe} \\
\left(\times 10^{5} \mathrm{~cm} / \mathrm{h}\right)\end{array}$ & $\begin{array}{c}\text { LT } \\
(\mathrm{h})\end{array}$ \\
\hline CPZ alone & $6.8 \pm 0.7$ & $11.1 \pm 0.3$ & $10.7 \pm 1.3$ & $12.4 \pm 1.2$ \\
with $\beta$-CyD & $6.6 \pm 0.1$ & $7.4 \pm 1.2$ & $7.0 \pm 1.1$ & $12.3 \pm 0.2$ \\
with DM- $\beta$-CyD & $7.2 \pm 1.4$ & $6.5 \pm 1.1$ & $6.6 \pm 0.6$ & $11.4 \pm 1.3$ \\
with HP- $\beta-C y D$ & $7.5 \pm 1.9$ & $8.3 \pm 1.2$ & $8.9 \pm 0.4$ & $10.9 \pm 1.4$ \\
\hline
\end{tabular}

a ) Concentration of $\mathrm{CPZ}$ was $5.0 \times 10^{-2} \mathrm{M}$.

b) Concentration of $\mathrm{CyDs}$ was $3.75 \times 10^{-2} \mathrm{M}$.

c) Diffusion parameter. d) Partition parameter. e) Permeability constant. f) Lag time.

Table IV. Effects of $\mathrm{CyDs}^{\mathrm{a}}$ ) on the Photodecomposition of $\mathrm{CPZ}^{\mathrm{b}}$ ) in Dorsal Skin of Guinea Pigs

\begin{tabular}{|c|c|c|c|c|}
\hline \multirow[b]{2}{*}{ System } & \multirow{2}{*}{$\begin{array}{c}\text { Non-irradiation } \\
\begin{array}{c}\text { Amount of } \mathrm{CPZ} \\
\text { in skin } \\
\left(\mu \mathrm{g} / \mathrm{cm}^{2}\right)\end{array}\end{array}$} & \multicolumn{3}{|c|}{ Irradiation } \\
\hline & & $\begin{array}{c}\text { Amount of } \mathrm{CPZ} \\
\text { in skin } \\
\left(\mu \mathrm{g} / \mathrm{cm}^{2}\right)\end{array}$ & $\underset{(\%)}{\mathrm{CPZ}}$ & $\begin{array}{c}\text { Promazine } \\
\text { formed } \\
(\%)\end{array}$ \\
\hline $\mathrm{CPZ}$ alone & $135.2 \pm 17.4$ & $16.8 \pm 5.2$ & $87.4 \pm 1.5$ & $16.0 \pm 1.1$ \\
\hline with $\beta-\mathrm{CyD}$ & $41.0 \pm 3.6$ & $2.3 \pm 0.3$ & $94.4 \pm 0.8$ & $28.8 \pm 2.8^{*}$ \\
\hline with $\mathrm{DM}-\beta-\mathrm{CyD}$ & $46.6 \pm 10.5$ & $4.4 \pm 0.0$ & $90.4 \pm 0.5$ & $33.6 \pm 1.2^{*}$ \\
\hline with $\mathrm{HP}-\beta-\mathrm{CyD}$ & $43.8 \pm 5.3$ & $2.9 \pm 0.4$ & $93.4 \pm 1.0$ & $17.6 \pm 2.7$ \\
\hline
\end{tabular}

a) Concentration of $\mathrm{CyDs}$ was $5.0 \times 10^{-2} \mathrm{M}$.

b) Concentration of $\mathrm{CPZ}$ was $5.0 \times 10^{-2} \mathrm{M}$.

c) Based on the reacted $\mathrm{CPZ}$ after photoirradiation for $63 \mathrm{~min}$ at $25^{\circ} \mathrm{C}$.

Each value represents the mean \pm S.E. of 5 guinea pigs.

$* p<0.05$ versus $\mathrm{CPZ}$ alone.

$\mathrm{CPZ}$ の拡散係数ならびに lag time は, $\mathrm{CyD}$ 包 接によりほとんど影響を受けなかった。一方, 透 過係数は分配係数の大きさに対応して, 各 $\mathrm{CyD}$ 包接により減少した（相関係数 $\mathrm{r}=0.971$ ). 以上 の結果から, $\mathrm{CyD}$ 複合体化にともなら $\mathrm{CPZ}$ の 膜透過の抑制は, 主に膜に対する $\mathrm{CPZ}$ の親和性 の低下に起因するものと考学られる.

\section{4. 皮膚中における $\mathrm{CPZ}$ の光分解反応に及ぼ す CyD の影響}

$\mathrm{CPZ}$ の光毒作用は, 光照射により生成するフ リーラジカルなどの反応中間体，スルフォキサイ ド, 重合体などの分解産物が生体成分に損傷を与 えることにより発現することが報告されてい $3^{20,21)}$.そこで, モルモット皮膚中に存在する $\mathrm{CPZ}$ の光照射により生成される光分解産物およ び反応中間体であるカチオンラジカル $\left(\mathrm{CPZ}^{+}\right)$の 生成に及ぼす $\mathrm{CyD}$ の影響を検討した。

Table IV は, 皮膚中に批子る $\mathrm{CPZ}$ の光分解 反応に及ぼす $\mathrm{CyD}$ の影響を示す. 3 種の $\mathrm{CyD}$
は, いずれも $\mathrm{CPZ}$ の光分解率にはほとんど影響 を与光ないのに対して, 光反応性には変化を与 光, $\mathrm{CPZ}$ の脱クロル体でめり, 分解産物の中で 比較的低毒性の $\mathrm{PZ}$ を多く生成した。またその度 合は, 複合体の安定度定数の大きさとよく対応 し, $\mathrm{DM}-\beta-\mathrm{CyD}>\beta-\mathrm{CyD}>\mathrm{HP}-\beta-\mathrm{CyD}$ の順で あった.な拉, $\mathrm{CPZ}$ の皮膚代謝に拈いて $\mathrm{PZ}$ は生成 されないことが知られているため ${ }^{22,23)}$, 皮膚中に 観察された $\mathrm{PZ}$ は, $\mathrm{CPZ}$ の光分解により産生し たものと考学らる。 また水溶液中に打ける $\mathrm{CPZ}$ の光分解反応に扣いても同様な脱クロル反応が観 察されることから ${ }^{15)}$, 皮膚中に和ける $\mathrm{CPZ}$ の光 反応性の変化は, $\mathrm{CyD}$ との複合体形成により $\mathrm{PZ}$ が優先的に生成する経路が主であると考学られ る.

Fig. 6 は, $\mathrm{CPZ}$ およびその $\mathrm{CyD}$ 混液を含む 濾紙を 3 時間貼布した皮膚を摘出後, 減圧乾燥 し, 室温で 5 分間光照射して得られたクロルプロ マジンカチオンラジカル $(\mathrm{CPZ}+)$ の電子スピン共 


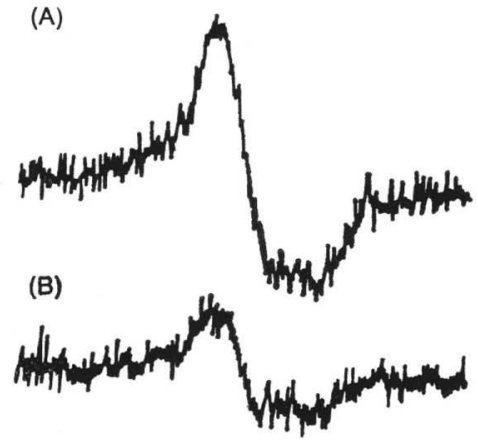

(C)
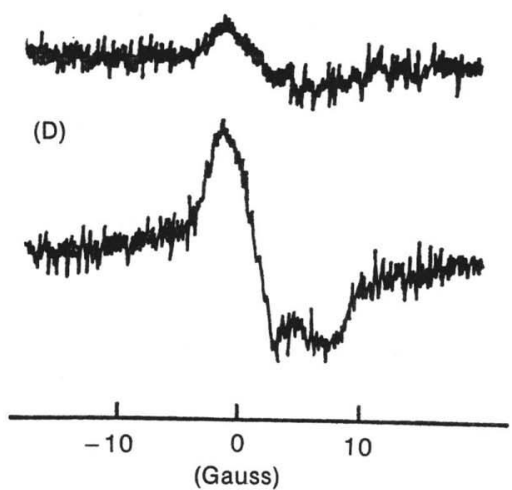

Fig. 6. ESR Spectra of Radical produced from $\mathrm{CPZ}\left(5.0 \times 10^{-2} \mathrm{M}\right)$ in the Absence and Presence of $\mathrm{CyDs}\left(5.0 \times 10^{-2} \mathrm{M}\right)$ after Application to Dorsal Skin of Guinea Pigs

(A) : $\mathrm{CPZ}$ alone, (B ) : $\mathrm{CPZ}+\beta-\mathrm{CyD}, \quad$ (C) : $\mathrm{CPZ}+\mathrm{DM}-\beta-\mathrm{CyD}$, (D) : CPZ $+\mathrm{HP}-\beta-\mathrm{CyD}$.

鳴 (ESR) スペクトルを示す.

本測定条件下では， $\mathrm{CPZ}$ ! はブロードなスペク トルを示し, 微細構造は観察されなかった. また， 他の光分解産物や皮膚成分由来のラジカル ${ }^{24)}$ は認 められなかった. Table V は, CPZ! の ESR ス ペクトルの特性パラメータを示す. $\mathrm{CyD}$ 存在下 に挴いて CPZ! の共鳴位置（ $\mathrm{g}$ 值）や線幅に顕著 な変化は認められなかったが, 一方, シグナル強 度は小さくなり ( $\mathrm{CPZ}$ alone $>\mathrm{HP}-\beta-\mathrm{CyD}>\beta-$ $\mathrm{CyD}>\mathrm{DM}-\beta-\mathrm{CyD}), \mathrm{CPZ}$ ! 生成の減少がタられ た.これらの結果は, CyD が CPZ! を経由して 生じる毒性の強いスルフォキサイドや重合体の生 成を抑制することを示唆する。

以上の知見より, $\mathrm{CyD}$ 複合体形成による $\mathrm{CPZ}$ の光接触性皮膚反応の抑制効果は, 皮膚表面また は皮膚中での CPZ の光分解反応性の変化に伴い,
Table V. ESR Parameters of the Radical Produced from $\mathrm{CPZ}^{\mathrm{a}}$ ) with and without $\mathrm{CyDs}^{\mathrm{b})}$ in Dosal Skin of Guinea Pigs, Photoirradiation for $5 \mathrm{~min}$ at $20^{\circ} \mathrm{C}$

\begin{tabular}{lccc}
\hline \hline System & $\begin{array}{c}\mathrm{Ic} \text { ) } \\
\text { (arbitrary } \\
\text { unit }\end{array}$ & g-value & $\begin{array}{c}\left.\Delta \mathrm{H}_{\mathrm{pp}} \mathrm{d}\right) \\
\text { (gauss) }\end{array}$ \\
\hline CPZ alone & 1.00 & 2.006 & 8.4 \\
with $\beta$-CyD & 0.42 & 2.005 & 8.3 \\
with DM- $\beta$-CyD & 0.38 & 2.005 & 8.6 \\
with HP- $\beta$-CyD & 0,88 & 2.005 & 8.4 \\
\hline
\end{tabular}

a) Concentration of $\mathrm{CPZ}$ was $5.0 \times 10^{-2} \mathrm{M}$.

b) Concentration of $\mathrm{CyDs}$ was $5.0 \times 10^{-2} \mathrm{M}$.

c) Peak-to-peak height of the first derivative curve.

d) Peak-to-peak width of the first derivative curve.

毒性の強い光分解産物の生成が抑制されることも その一因となっているものと推察される。

\section{結 論}

本研究で得られた知見は, 以下の 1)〜4）のよ らに総括される。

1） $\mathrm{CPZ}$ 和よびその $\mathrm{CyD}$ 混液を含む濾紙を モルモット皮膚に貼布後, 光照射により惹起され る皮膚反応を, 肉眼的および病理組織学的に観察 した結果, $\mathrm{CyD}$ 存在下で顕著な抑制が認められ， その度合は複合体の安定度定数の大ささに対応し $\tau, \mathrm{DM}-\beta-\mathrm{CyD}\left(8800 \mathrm{M}^{-1}\right)>\beta-\mathrm{CyD}\left(8300 \mathrm{M}^{-1}>\right.$ $\mathrm{HP}-\beta-\mathrm{CyD}\left(4400 \mathrm{M}^{-1}\right)$ の順であった.

2） $\mathrm{CPZ}$ の経皮吸収量は $\mathrm{CyD}$ 添加により低 下したが，その効果は 3 種の $\mathrm{CyD}$ 間でほとんど 差が認められなかった. 皮膚中に存在する $\mathrm{CPZ}$ の分布状態を観察すると, 薬物単独では角質層お よびそれ以下の組織中にほぼ同じ割合で存在し た. 一方, DM- $\beta-\mathrm{CyD}$ 存在下では $\mathrm{CPZ}$ は角質 層に高濃度に分布し, 皮膚深部への浸透の抑制が みられた。

3）へアレスマウスの摘出背部皮膚を用いた $\mathrm{CPZ}$ の膜透過性に対する $\mathrm{CyD}$ の影響を比較す ると, DM- $\beta-\mathrm{CyD}>\beta-\mathrm{CyD}>\mathrm{HP}-\beta-\mathrm{CyD}$ の順に 抑制効果を示し，この現象は $\mathrm{CyD}$ との複合体形 成による $\mathrm{CPZ}$ の膜親和性の低下に起因するもの と推察された。

4）皮膚表面または皮膚中に拈いて，CyD は 
$\mathrm{CPZ}$ の光分解反応に影響を与え, 反応過程で生 じる CPZ：の生成を抑制するとともに， CPZ の 脱クロル体である低毒性の $\mathrm{PZ}$ を高收率に生成 乙, その効果は光毒性の軽減効果と同様に DM$\beta-\mathrm{CyD}>\beta-\mathrm{CyD}>\mathrm{HP}-\beta-\mathrm{CyD}$ の順であった.

以上のように， 3 種の $\mathrm{CyD}$ の中で特に $\mathrm{DM}$ $\beta-\mathrm{CyD}$ は, $\mathrm{CPZ}$ の光接触性皮膚反応を顕著に抑 制することが確かめられた.この光毒性軽減効果 は, DM- $\beta$-CyD が CPZ の皮膚への移行を抑制 し, さらに, 薬物の皮膚中分布や皮膚中での光反 応性を変化させることによるものと推察された。
を企図する際に $\mathrm{DM}-\beta-\mathrm{CyD}$ の有効利用を示唆 するものであり，また皮膚科領域に拈ける薬物の 安全性と有効性を確保する上で有用な基礎資料に なるものと考光られる。

\section{謝 辞}

本研究にあたり, 有益なる御指導と御助言を賜 った熊本大学薬学部平山文俊博士, また, 病理組 織学的検討に颃いて有益なる御助言と御鞭撻を頂 いた熊本大学病院皮䖉科小野友道博士に感謝致し ます. さらに本研究に協力された平木恵氏に感謝 致します。

\section{文献}

1）野村 茂: 職業性皮膚障害と云の対策, 労研出版 (1974).

2) Saenger, W. : Cyclodextrin inclusion compounds in research and industry. Angew. Chem. Int. Ed. Engl., $19: 344-362$ (1980).

3）上釜兼人：シクロデキストリン Complex の製剤への応用. 薬学雑誌, 101（10）: 857-873 (1981).

4) Hoshino, T., Ishida, K., Irie, T., Hirayama, F. and Uekama, K. : Alleviation in protriptyline-photosensitized skin irritation by di-O-methyl- $\beta$-cyclodextrin complexation. Int. J. Pharm., 38 : 265-267 (1987).

5) Uekama, K. and Otagiri, M. : Cyclodextrins in drug carrier systems, CRC Clitical Reviews in Therapeutic Drug Carrier Systems. Vol. 3, CRC Press, Boca Raton, Fla., 1987, pp.1-40.

6) Uekama, K. : Pharmaceutical applications of methylated cyclodextrins. Pharm. Int., $6: 61-65$ (1985).

7) Pitha, J., Milecki, J., Fales, H., Pannell, L. and Uekama, K. : Hydroxypropyl$\beta$-cyclodextrin : preparation and characterization; effects on solubility of drugs. Int. J. Pharm., $29: 73-82$ (1986).

8) Szejtli, J. : Dimethyl- $\beta$-cyclodextrin as parenteral drug carrier. J. Incl. Phnom., $1: 135-150$ (1983).

9) Scott, R.L. : Some comments on the Benesi-Hildebrand equation. Rec. Trav. Chim., 75: 787-789 (1956).

10）後藤 茂: 生物薬剂学実験マニュアル, p. 122, 清至書院 (1985).

11）三友善夫, 高山昇二郎：臨床検查講座12病理学, 医歯薬出版 (1982).

12) Washitake, M., Yajima, T., Anmo, T., Arita, T. and Hori, R. : Studies on percutaneous absorption of drugs. III. percutaneous absorption of drugs through damaged skin. Chem. Pharm. Bull., 21 : 2444-2451 (1973).

13) Koizumi, K., Kubota, Y., Okada, Y. Utamura, T. : Microanalyses of $\beta$-cyclodextrin in plasma by highperformance liquid chromatography. J. Chromatogr., $341: 31-41$ (1985).

14) Bronaugh, R.L., Stewart, R.F. and Congdon, E.R.: Methods for in vitro percutaneous absorption studies II. animal models for human skin. Toxicol. Appl. Pharmacol., 62 : 481-488 (1982).

15) Uekama, K., Irie, T. and Hirayama, F. : Participation of cyclodextrin inclusion catalysis in photolysis of chlorpromazine to give promazine in aqueous solusion. Chem. Lett., 1978 : 1109-1112.

16) Epstein, S. : Chlorpromazine photosensitivity. Arch. Derm., $98: 354-363$ (1968).

17) 佐藤吉昭編：光線過敏症, p. 67, 金原出版 (1983).

18) Urbach, F.: The biologic effects of ultraviolet radiation with emphasis on the skin, Pergamon Press, Oxford (1969). 
19) Okamoto, H., Komatsu, H., Hashida, M. and Sezaki, H. : Effects of $\beta$-cyclodextrin and di-O-methyl- $\beta$-cyclodextrin on the percutaneous absorption of butylparaben, indomethacin and sulfanilic acid. Int. J. Pharm., $30: 35-45$ (1986).

20) Kochevar, I.E. : Phototoxicity mechanisms : chlorpromazine photosensitized damage to DNA and cell membranes. J. Invest. Dermatol., $76: 59-64$ (1981).

21) Testylier, G., Daveloose, D., Leterrier, F., Buchmann, O. and Shimoni, M. : Photochemical binding of phenothiazines on biological membrane proteins. Photochem. Photobiol., 39 : 273-276 (1984).

22) Beckett, A.H., Beaven, M.A. and Robinson, A.E. : Metabolism of chlorpromazine in humans. Biochem. Pharmacol., $12: 779-794$ (1963).

23）中島 啓：向精神薬の吸収・代謝・排泄, 月刊薬事, $17: 1171-1179$ (1975).

24）小西良平, 杴山正康, 三嶋祐治, 熊野修治：表皮のフリーラジカル，西日皮膚，46： 1093-1099 (1984). 